\title{
Socio-environmental success or failure of Extractive Reserves in the Amazon?
}

\author{
Sucesso ou fracasso socioambiental de Reservas Extrativistas na Amazônia? \\ Éxito socioambiental o fracaso de las Reservas Extractivas en la Amazonía?
}

Received: 04/04/2021 | Reviewed: 04/12/2021 | Accept: 04/16/2021 | Published: 04/30/2021

\author{
Josimar da Silva Freitas \\ ORCID: https://orcid.org/0000-0002-6242-9748 \\ Federal University of Pará, Brazil \\ E-mail: josimarfreitas55@gmail.com \\ Armin Mathis \\ ORCID: https://orcid.org/0000-0002-7831-9391 \\ Federal University of Pará, Brazil \\ E-mail: armin.mathis@ufpa.br \\ Marcellus Marques Caldas \\ ORCID: https://orcid.org/0000-0003-3086-7054 \\ Kansas State University, United States \\ E-mail: caldasma@ksu.edu \\ Alfredo Kingo Oyama Homma \\ ORCID: https://orcid.org/0000-0003-0330-9858 \\ Embrapa Eastern Amazon, Brazil \\ E-mail: alfredo.homma@embrapa.br \\ Milton Cordeiro Farias Filho \\ ORCID: https://orcid.org/0000-0003-2570-201X \\ Federal University of Pará, Brazil \\ E-mail: mcffarias@gmail.com \\ Alexandre Almir Ferreira Rivas \\ ORCID: https://orcid.org/0000-0003-1794-8909 \\ Federal University of Amazonas, Brazil \\ E-mail: central.rivas@gmail.com \\ Kennedy Maia dos Santos \\ ORCID: https://orcid.org/0000-0002-2697-313X \\ Northern Educational Union, Brazil \\ E-mail: kmaisekel@hotmail.com
}

\begin{abstract}
Brazilian public institutions have difficulties in building relationships of trust that truly promote sustainable development. This study proves that the Extractive Reserves (RESEX) socio-environmental crisis occurs due to the interdependent relationship that exists between environmental, economic, social groups and institutional organizations. The study concludes that the implementation of public policies regarding health, education, transportation, communication, technical assistance, energy, as well as the current revenues from the productive activities of extractivism, agriculture, and cattle ranching was ineffective, because the state did not cooperate with strategies to alleviate the conflict between conservation and development.
\end{abstract}

Keywords: Conservation; Development; Extractive Reserves.

\section{Resumo}

As instituições públicas brasileiras têm dificuldades em construir relações de confiança que realmente promovam desenvolvimento sustentável. Este estudo comprova que a crise socioambiental das Reservas Extrativistas (RESEX) acontece em razão da relação de interdependência que ocorre entre os grupos ambiental, econômico, social e institucional. Este estudo conclui que a implementação de políticas públicas de saúde, educação, transporte, comunicação, assistência técnica, energia, bem como as atuais receitas das atividades produtivas de extrativismo, agricultura e pecuária bovina foram ineficazes, porque o Estado não cooperou para amenizar o conflito entre conservação e desenvolvimento.

Palavras-chave: Conservação; Desenvolvimento; Reservas Extrativistas. 


\section{Resumen}

Las instituciones públicas brasileñas tienen dificultades para construir relaciones de confianza que realmente promuevan el desarrollo sostenible. Este estudio demuestra que la crisis socioambientral de las Reservas Extractivas (RESEX) se produce debido a la relación interdependencia que se produce entre los grupos ambientales, económicos sociales y institucionales. Este estúdio concluye que la implementación de políticas públicas en materia de salud, educación, transporte, comunicación, asistencia técnica, energía, así como los ingresos actuales de las actividades productivas del extractivismo, la agricultura y la ganadería eran ineficaces, porque el Estado no cooperó para aliviar el conflictoentre conservación y desarrollo.

Palabras clave: Conservación; Desarrollo; Reservas Extractivas.

\section{Introduction}

Forests are critical habitats for biodiversity and provide essential ecosystem services that meet human needs and ensure climate balance (Simioni et al., 2020). Forests also perform indispensable cultural functions for traditional communities, either through food benefits and the cure of diseases or by maintaining beliefs, rituals, customs, and habits over generations (Walker et al., 2020).

However, the exploitation of environmental resources has caused the degradation of forests worldwide, especially in tropical countries (Choksi, 2020). Nowhere in the world have concerns about the future of forests attracted as much attention as in Brazil. This country contains 22\% of the planet's humid tropical forests and 58\% of South America (Inpe, 2020). However, deforestation rates here are also among the highest in the world, which reduced from 2004 to 2014 but rose from 2015 (Stropp et al., 2020). The Amazon biome has lost $20 \%\left(700.000 \mathrm{~km}^{2}\right)$ of its primary and secondary forests since the $1970 \mathrm{~s}$, representing an area twice as big as Germany (Inpe, 2020).

To alleviate this problem, the Brazilian government implemented several policies, including the development of conservation units (UCs). UCs are areas with significant natural resources (Krasnov, 2020); the main goal of these units is protecting and conserving environmental resources against anthropic pressure (Silva et al., 2020). Among the UCs are the Extractive Reserves (RESEX), created with the objective of improving the quality of life and well-being of traditional communities while seeking to ensure environmental conservation through sustainable management of natural resources (Fearnside et al., 2018; Costa, 2018; Gomes et al., 2012).

In the Amazon, the first RESEX were instituted in the 1990s in response to the advance of the agricultural frontier, high rates of deforestation, the loss of biological diversity, and growing social conflicts between traditional populations and powerful farmers (Silva \& Silva, 2019; Santana \& Pedroso, 2019; Collins \& Mitchard, 2017; Salisbury \& Schimink, 2007).

However, after three decades of its existence, the local inhabitants have begun productive activities incompatible with the ideals of the resource use management plan of the RESEX (Gomes et al., 2012; Vadjunec et al., 2009). In other words, the local inhabitants who were previously focused on the harvest of non-timber forest products and subsistence agriculture switched to other non-environment-friendly activities, such as ranching (Kröger, 2019; Maciel et al., 2018).

Although the literature on extractive economy and Non-Timber Forest Products (NTFPs) is rich in arguments that seek to explain this transition (e.g., low supply, lack of relevant financial support in the form of subsidies and development programs, and weak regional markets), it does not guarantee subsistence support for families and competitiveness with income from traditional agriculture (Turini, 2014; Homma, 2012; Soares-Filho et al., 2013; Hall, 2004; Jaramilo-Giraldo et al., 2017; Lopes et al., 2018; Carvalho Ribeiro et al., 2018; Hecht, 2013; Humphries et al., 2012).

Few studies have evaluated the institutional role of the federal government in evaluating the success or failure of the RESEX (Calegare \& Higuchi, 2018; Corrigan et al., 2018). Therefore, the objective of this study is to fill the gap in literature by evaluating the role of the state in promoting the success or failure of RESEX in the Brazilian Amazon. In addition, we seek to identify the factors that influenced the changes in the productive activities of the local inhabitants. 
This paper is organized into four sections. First, we discuss the dilemma of conservation and development. Second, we present the study area and data collection. Third, we evaluate and discuss the results. Finally, we present the main conclusion of the study.

\section{The Dilemma of Conservation and Development of RESEX}

Global challenges are often localized and associated with anthropic pressure (Rohde et al., 2020) such as energy stress (e.g., oil production crisis), environmental problems (e.g., deforestation, lack of water, and population growth), and climate change, all of which catastrophically threaten the world order (Homer-Dixon, 2006).

In Brazil, particularly in the Amazon, traditional communities (e.g., rubber tappers) defending the forest resulted in conflicts and crises with the state and large agribusiness producers, just like gained international strategic importance (Bezerra, 2012). In the 1970s and 1980s, the rubber tappers of the region were threatened by the burning of their residences and destruction of subsistence agriculture; they were arrested and tortured by civil and military police, prevented from entering their rubber communities, and forced to sign false documents that benefited farmers and ranchers from other regions of Brazil (Silveira, 2018; McAdam et al., 1996).

During this period, there was an international debate on the conservation of natural resources, and social movement organizations raised concerns that the economic development plan of Brazil was destroying the Amazon (Schwartzman, 1986; Allegretti, 2002). Chico Mendes, leader of the rubber tapper movement in the Brazilian Amazon, received support from environmentalists, political scientists, union leaders, political parties, and the regional and international press to inform people about the value of the forest and to denounce the inhumane actions being inflicted upon the traditional communities (Allegretti, 2008; Sawyer, 2013).

Amid the conflicts, with support from international organizations, the rubber tapper movement association presented a proposal which gained strength in the 1980s, to promote social justice, fight poverty, and conserve the cultural and environmental diversity of the region (Almeida et al., 2018). This collective action of the rubber tappers resulted in the creation of Extractive Reserves (RESEX) based on both the collective rights of traditional communities and their sustainable forms of livelihood (Almeida, 2004). The RESEX thus emerged based on indigenous reserves and rubber extraction while promising to rescue the local traditional culture and ensure the ecological balance of the Amazon rainforest (Schwartzman,2018). In contrast to the statesponsored destructive development model, RESEX were anchored in the idea of traditional communities that use the forest as their way of life (Allegretti, 1990).

In 1990, when the first four RESEX (Alto Juruá, Chico Mendes, Rio Ouro Preto, and Rio Cajari) were created in the Brazilian Amazon, the challenges were to conserve 2.2 million hectares of forests and feed thousands of families while reducing socio-economic inequalities (Cunha \& Almeida, 2004). Proponents of the RESEX argued that the reserves would provide the following benefits: reduction of deforestation and burning rates, ecosystem integrity, cultural maintenance identity, and livelihood to the traditional communities (Allegretti \& Schwartzman, 1987; Anderson, 1990; Hall, 1997; Nepstad et al. 2006).

In this sense, conservationists were concerned about the impacts and maintenance of forests (Redford, 1992; Fearnside, 1996), as well as the protection of ecosystems (Peres, 2000). In turn, the developmentalists defended their socioeconomic theses based on the following points: socio-economic development, social justice, inequalities and low access to social policies (Dantas et al., 2020), subsistence difficulties (Haddad et al., 2019), contempt toward agricultural policies (Homma, 2020), and socioeconomic vulnerability of RESEX (Geisler \& Silberling, 1992; Browder, 1992).

It is necessary the integration of the two currents (conservationists and developmentists) of researchers for the maintenance and performance of productive activities of extractivism (e.g., extraction and collection of latex from Brazil nuts), agriculture (hunting, fishing and swidden) and livestock (aviculture, pig farming, and cattle) (Rylands \& Brandon, 2005; Costa, 
2012; Homma, 2013). The integration ensures the combination of productive activities with technologies, reduction of deforestation, burning and improvement of the living conditions of traditional communities (Kainer et al., 2018; Shanley et al., 2018).

These strategies are important because agriculture and livestock are two productive activities that cause greatest environmental impact (Smeraldi \& May, 2008; Teixeira et al., 2018; Kröger, 2019, p. 13), whether for the economic highlight (Siviero et al., 2019) and the support of rural credits (Merry \& Soares-Filho, 2017; Maciel et al., 2018). For example, the economic situation may have caused a $120 \%$ increase in cattle prices, $88 \%$ decrease in rubber prices, and $32 \%$ decrease in Brazil chestnut prices (Wallace et al., 2018).

This context is influenced by regional agents, and in turn challenges the local family farming model (Pédelahore et al., 2020) and involves new local contractual relations (Cochet, 2008; Harff \& Lamarche, 1998). This reaffirms the influence of the external environment, market forces, and social organization of agents (White, 1981; Liljenberg, 2005; Steiner, 2007; Capelari et al., 2020); the structure of network capitalism and socio-economic relations (Boltanski \& Chiapello, 1999; Granovetter, 2000; Bolčić, 2014); and the dynamics of the cultural, social, and economic life of agents of the RESEX (Steiner, 2005; Allaire, 2010).

With 31 years of existence (1990-2021), the purposes of the RESEX were considered fulfilled for several reasons, such as the loss of economic importance of extractive products in the region following government subsidy cuts that marked the early stages of RESEX, difficulties in acquiring markets for Non-Forestry Timber Products, price drop and strong competitiveness with other activities, low productivity of land and manpower, and inefficient forest protection (Drummond, 1996; Siviero et al., 2019, p. 361; Jaramillo-Giraldo et al., 2017, p. 191; Schwartzman, 2018, p. 70).

\section{Method}

\subsection{Study area}

This research focused on the first three and largest RESEX created in the Brazilian Amazon in the 1990s: RESEX Alto Juruá, RESEX Rio Ouro Preto, and RESEX Rio Cajari. Figure 1 provides their geographical locations. 
Figure 1 - Location of RESEX Alto Juruá, Rio Ouro Preto, and Rio Cajari.

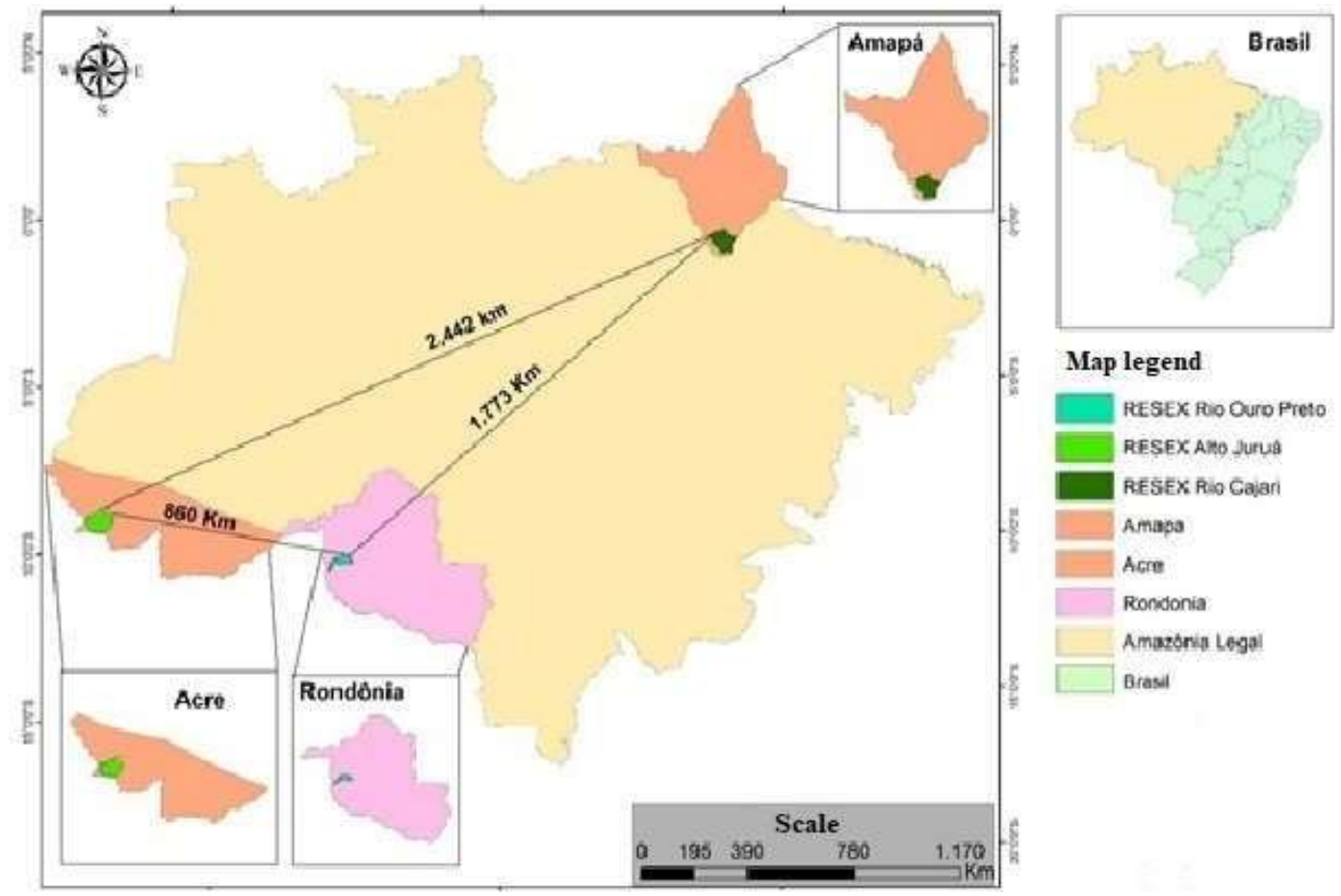

Source: Author (2017).

The RESEX Alto Juruá is located in the municipality of Marechal Thaumaturgo in the State of Acre. This RESEX of 537.946 hectares was created by decree 98.863 of 1990. In 2010 ${ }^{1}, 4.170$ people lived in the area divided into 80 communities on the banks of the Juruá, Tejo, Amônia, Amônia, Breu, and Manteiga rivers (Ibge, 2010). Cattle ranching and production of cassava flour and tobacco are the main activities that support the local economy.

The RESEX Rio Ouro Preto was created in the municipalities of Guajará-Mirim and Nova Mamoré. This wasestablished with 204.631 hectares by decree 99.166 of 1990. In 2010, it contained 699 residents, distributed across 12 communities on the banks of the Ouro Preto River and the back roads (Ibge, 2010). The main economic activities of this RESEX are cattle farming, Brazil nut growth, and cassava flour production.

The last RESEX under evaluation is Rio Cajari, founded by decree 99.145 of March 1990. This is located in the municipalities of Laranjal do Jari, Mazagão, and Vitória do Jari and has an area of 481.650 hectares, where 2.293 inhabitants live in 31 communities.

\subsection{Study delineation}

Data collection occurred through the association method, and we found dependence (interference) between variables of the groups: social, economic, environmental and institutional. For example, the low number of health units, schools, professionals, technical assistance, and low supply of renewable or thermoelectric energy are associated with insignificant investments by institutional organizations. In addition, the low income from the productive activities of extractivism, agriculture and livestock, as well as the accumulations of deforestation, reduction of fish and hunting of wild animals are associated with irrelevant incentives of institutional organizations.

This dependence occurs because there is a systematic procedure, studied here at the environmental, sociological,

\footnotetext{
${ }^{1}$ We did not find more recent data because the last Demographic Census occurred only in 2010.
} 
economic and institutional levels. (Volpato, 2015). In this sense, the central focus is not on the variables or groups studied but on the resulting relationships (Volpato, 2013). The evidence of association between two variables or two groups gives us reasons to believe that there is a causal relationship affecting the variables or groups under scrutiny (Elster, 1994).

\subsection{Specific procedures and data analysis}

In Brazil, there are 65 marine and terrestrial federal RESEX distributed among four biomes: 35 in the Amazon, 5 in the Cerrado, 1 in Caatinga, and 1 in the Atlantic Forest (Icmbio, 2021). We consider the RESEX Alto Juruá, Rio Ouro Preto and Rio Cajari to be the choice regions, as they were the first to be created in Brazil. In addition, they collaborate with collection of information on environmental resources, deforestation, burning, subsistence conditions, residents' income, the situation of the provision of health and education services, and assessment of the ineffectiveness or ineffectiveness of public policies of institutional organizations.

Data collection involved audio interviews with 232 heads of household or household guardians who had lived for at least a decade in each RESEX. This sample is representative because the procedures were random and reproduced the reality of the interviewees. The temporality of at least ten years ensures the interviewee's knowledge of the environmental, economic, social, and institutional structure of the RESEX. Entry into the field and data collection occurred only after the issuance of a license by the Authorization and Information System on Biodiversity (SISBIO), which is the tool of the Chico Mendes Institute for Biodiversity Conservation (ICMBio) that issues authorizations to researchers to conduct studies in UCs.

The 232 heads were distributed as follows: 64 in the Upper Juruá, 67 in Rio Ouro Preto, and 101 in Rio Cajari (101). In addition, the displacements in the RESEX involved long distances and bad vicinal roads; such interviews were carried out by providing transportation such as commercial flights and pickup trucks.

The research instrument used consists of 38 questions divided into 4 groups. In the social group, the issues concerned the Bolsa Verde Program, deforestation, burning, forests, and environmental resources. In the economic group, the issues were related to extractive production, agriculture, cattle ranching, rural credits, soil management, country roads, transport, agricultural equipment, and household income. In the social group, the main themes were sex, birth, migration, education level, and the functioning of the education and health system. In the institutional group, the most relevant issues were the situation of education and health, productive incentives, management, and implementation of public policies in RESEX. The survey was conducted between January and March 2017.

The interviewees identified themselves as rural producers involved in a combined production of extractivism, agriculture, and livestock. However, the RESEX presented distinctions in relation to the potential of fauna and flora, inhabitants, and local management. Alto Juruá and Rio Ouro Preto showed similarities with regard to the characteristics of the inhabitants, cattle production activity, and advance of deforestation. Rio Cajari differed from the other two because it presented a higher supply of Brazil nuts, lower deforestation, and the existence of the Quilombola community.

Further, a qualitative approach was necessary for the analysis of the interviewees' information, and the quantitative or descriptive frequency statistics allowed the performance of correlation tests, mean, median, mode, and variance (Volpato, 2016). We also used a spatial analysis of vector and matrix data for map construction; the main references used for vector data, drainage, locality, and hydrography were the Brazilian Institute of Geography and Statistics (IBGE), National Water Agency (ANA), Management Plans, and National Institute of Space Resear (INPE/PRODES).

\section{Results and Discussion}

Figure 2 shows the interviewees' perceptions regarding public policies and the major problems experienced in the RESEX Alto Juruá, Rio Ouro Preto, and Rio Cajari. 
Figure 2 - Ineffectiveness of public policies in RESEX.



Source: Field research (2017).

At Alto Juruá, based on the interviewees' perceptions, fish reduction, low energy supply, lack of technical assistance, communication difficulties, low transport supply, lack of professionals and health units, and low supply of schools and teachers were associated with the ineffectiveness of public policies. At Rio Ouro Preto, the problems were similar, because the low availability of schools and teachers, absence of professionals and health units, low transport supply, communication difficulties, and lack of technical assistance were associated with the ineffectiveness of public policies. At Rio Cajari, inefficiency was associated with low energy supply, communication difficulties, low transportation supply, lack of technical assistance, low availability of schools and teachers, and lack of health professionals and units.

These problems occur because the state does not invest quantitatively and adequately in financial and human resources to reduce the social problems highlighted by residents. Therefore, the state does not consider local populations (Quaresma, 1998); hinders improvement in the living conditions of the inhabitants; and does not ensure well-being of the inhabitants (Drummond et al., 2012), subsistence (Françoso et al., 2015), and biodiversity maintenance (Bockstael et al., 2016). For these reasons, the interviewees suggested that the state should modify public policies to alleviate social decline. Figure 3 demonstrates the interviewees' perceptions of the state's attention to residents through the implementation of public policies, as well as the future of the children of Alto Juruá, Rio Ouro Preto, and Rio Cajari. 
Figure 3 - Based at the institutional behavior.

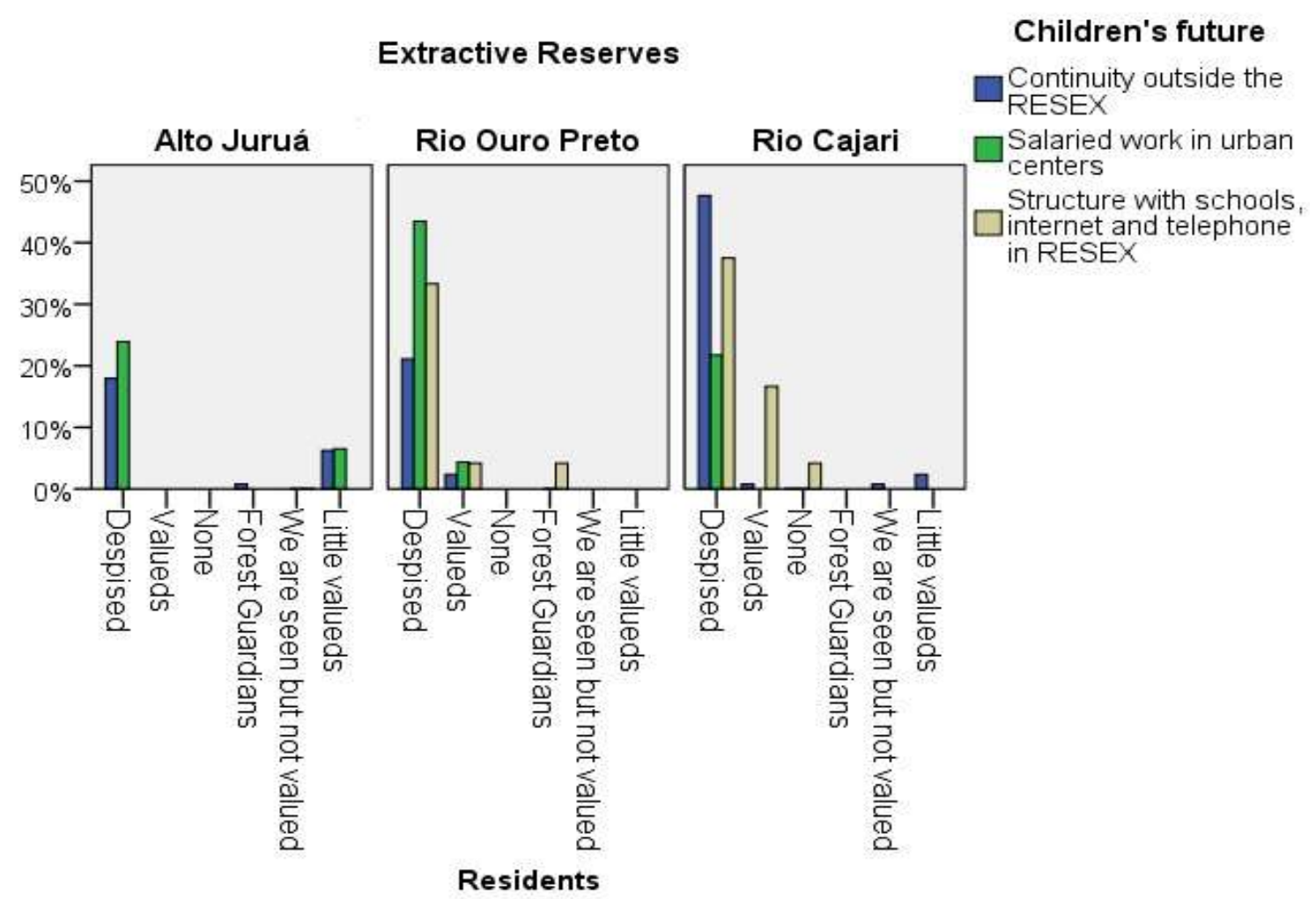

Source: Field research (2017).

Residents of the RESEX are dissatisfied with institutional actions, since they affirm that ineffectiveness in the implementation of public policies makes it difficult to improve the living conditions of inhabitants. The contempt evidenced by the state in the three RESEX is characterized by low social and economic investments. This situation occurs because the state prioritizes projects aimed at environmental conservation, and little importance is given to social development.

For example, in Alto Juruá and Rio Ouro Preto, the parents or guardians prefer that their children migrate to urban areas in search of work and income, while at Rio Cajari, educational continuity is prioritized. The inhabitants of RESEX have lost confidence in public institutions since they have not succeeded in these three decades, and the main concern of parents is the educational and professional future of their children.

The migration of children and adolescents to urban centers occurs because the state does not guarantee vacancies for elementary school and qualified teachers, specifically in the Floresta Canutama (79\%), Floresta Tapauá (64\%), RESEX Canutama (63\%), Reserves of Sustainable Development (RDS) Igapó-Açu (25\%), RDS of Matupiri (53\%), and PAREST of Matupiri (74\%) (Costa et al., 2015).

Other data that deserve attention are the number of elderly and retired people living in the RESEX: 11.69\% at Alto Juruá, $42.86 \%$ at Rio Ouro Preto, and $41.56 \%$ at Rio Cajari (Freitas, 2018). This reveals a high level of complexity, because the combination of the migration of young people in search of school continuity and high percentage of retirees negatively affects the model of environmental conservation and social development.

The vulnerability and ineffectiveness of the public policies of the institutional group (state) causes a relationship of dependence with the social group (local inhabitants), since the families of the RESEX are motivated to use more environmental resources to ensure subsistence. The inhabitants recognize the vulnerable situation of exclusion (Haddad et al., 2019, p. 96), 
difficulties in accessing health services and education (Brown, Rosendo, 2000), and other factors that affect local governance and conservation (Mooij et al., 2019).

The low attention shown by the state toward the residents of the RESEX justifies the lack of credits for productive activities and the impact on income from extractivism, agriculture, and cattle ranching (Figure 4).

Figure 4 - Income from productive activities in RESEX Alto Juruá, Rio Ouro Preto and Rio Cajari.

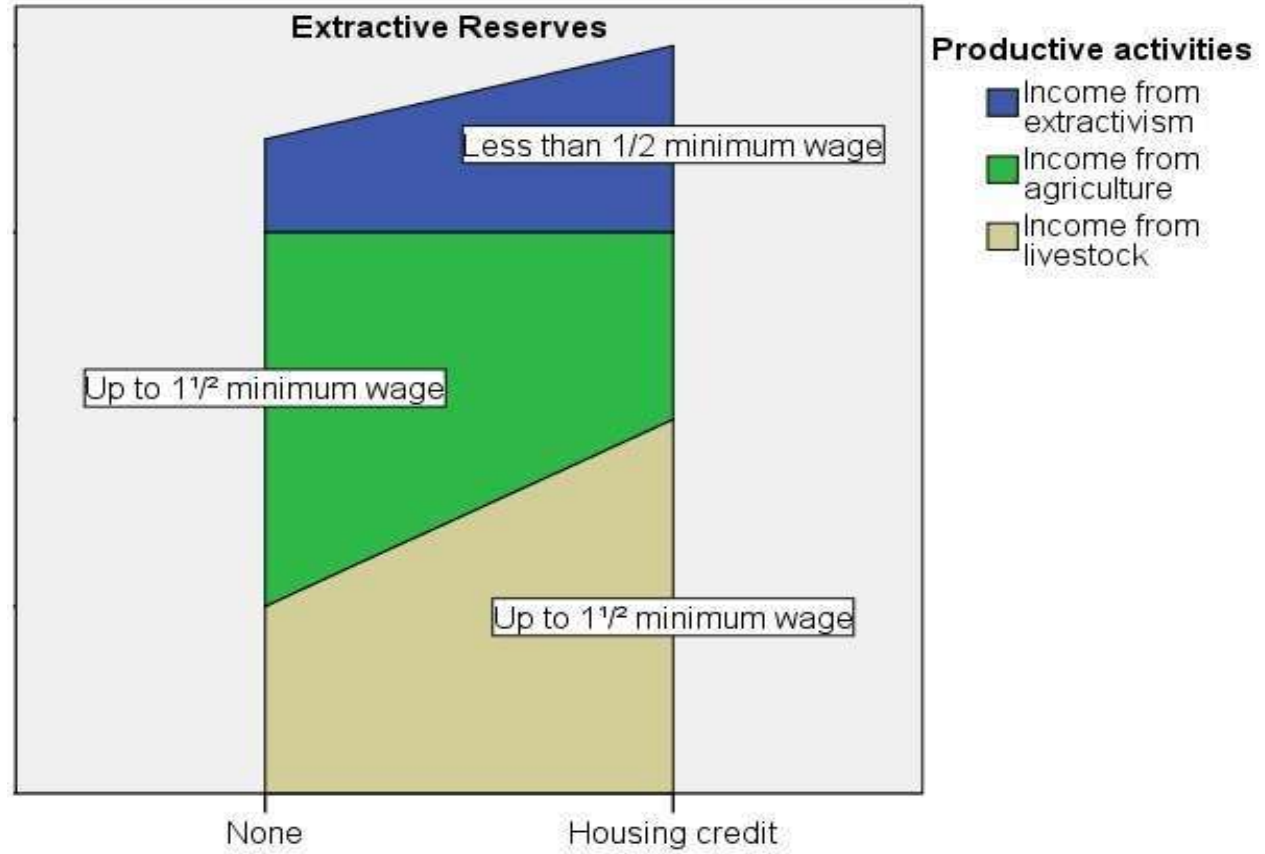

Credits for productive activities

Source: Field research (2017).

According to the interviewees, there was no subsidy through rural credits for the productive activities of extractivism, agriculture, and cattle ranching. In general, those who work in extractivism also practice agriculture. In specific cases, there is a combination of the three productive activities. The income reported in each activity corresponds to household income, and this combination is necessary to ensure family survival.

Considering the income from each production system of the RESEX, extractivism emerges as complementary income to agricultural and livestock production. Extractivism is not supported economically (Homma, 2015) due to market difficulties (Greissing, 2010), low prices of Brazil nuts and rubber (Silva \& Paraense, 2019), growth of agricultural activities (Cavalcante \& Goes, 2011), and mining (Clement, 2006).

According to Pantoja, Costa and Postigo (2009), 54.5\% of the families produced rubber, however, a decade later fell to $21 \%$ due to the growth of livestock ( $24.5 \%$ in 1991, and 50\% in 1998). These data justify that extractivism remains a potential supply and market until the emergence of new economic options (Homma, 2018), because the regional political economy develops alongside socio-economic dimensions (Thaler et al., 2019).

Despite the present equality of agricultural and livestock yields, the numbers of cattle and buffalo cattle have not been reported correctly, due to the rules contained in the management and use plan. There is also a growth trend due to the local market. Cattle numbers grow in RESEX, even though there is a limit of up to 20 heads allowed per family. 
Cattle ranching grows due to viability, diversification (Maciel et al., 2018), and economic guarantees (Gomes et al., 2012). The lack of social (Freitas \& Rivas, 2014), economic (Françoso et al., 2015), and environmental (Freitas et al., 2016) policies result in institutional inefficiency (Drummond et al., 2012).

In addition to the productive activities of extractivism, agriculture, and cattle ranching, Figure 5 shows the interviewees' perceptions of transfers (state) of income corresponding to Programs Bolsa Família, Bolsa Verde, and Aposentadoria of RESEX Alto Juruá, Rio Ouro Preto, and Rio Cajari.

Figure 5 - Income corresponding to Programs Bolsa Verde, Bolsa Família, and Aposentadoria.

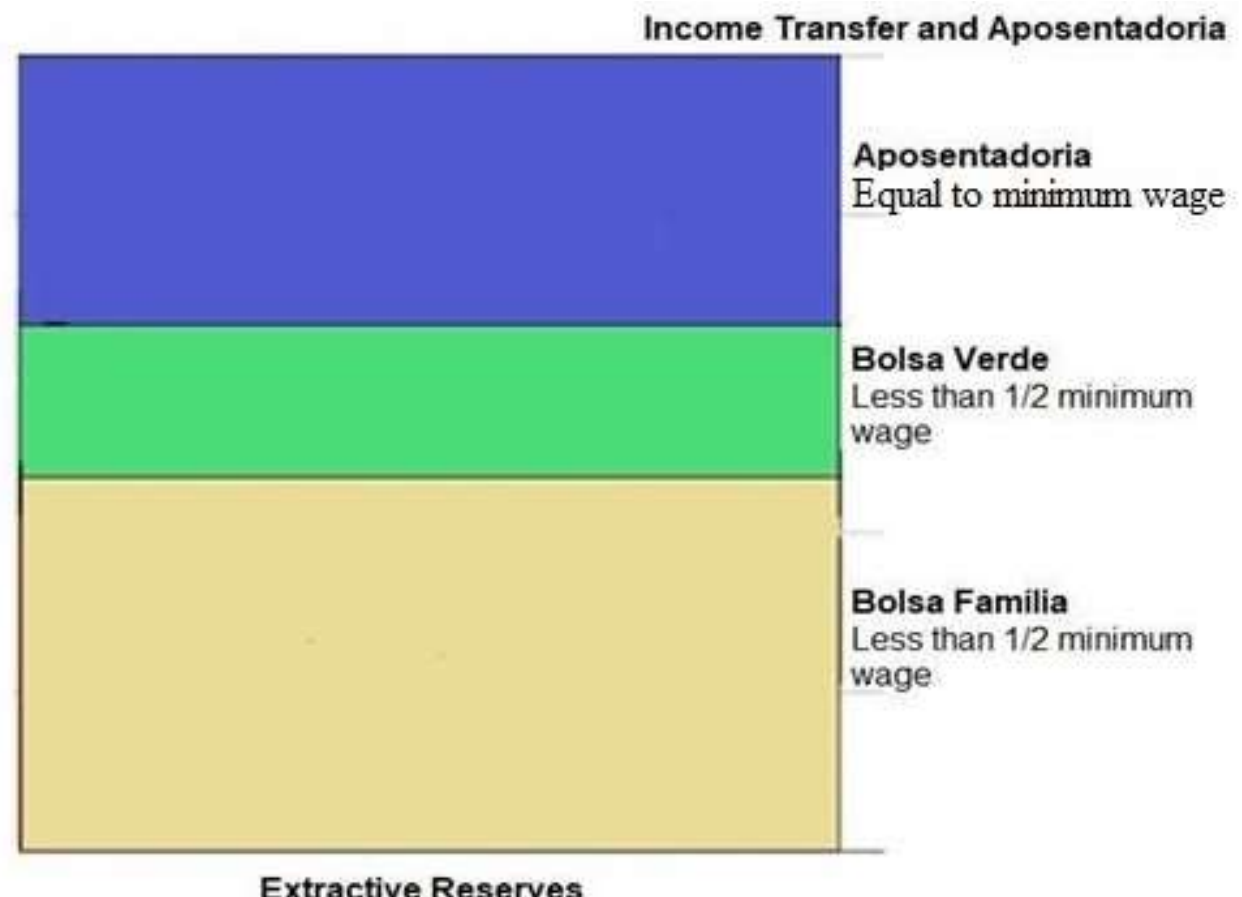

Source: Field research (2017).

Based on the information provided by the interviewees, the income from the Bolsa Família and Bolsa Verde Programs does not reach half the minimum wage. In turn, Aposentadoria (rural workers aged 60 years or older) is equivalent to the monthly minimum wage amount ( $\mathrm{R} \$ 1$ 110.00). Although the Bolsa Família and Bolsa Verde Programs are clientelists, these incomes collaborate in a complementary way with the productive activities of RESEX residents. Even after adding the income of productive activities to income transfers, the interviewees stressed that the earning was insufficient to ensure subsistence.

The Bolsa Família Program was created in 2003 with the objective of reducing extreme poverty in Brazil, but it faces management, implementation, and low-income challenges. The Program is affected not only by its institutional design but also by the different capacities of human resources, management, and articulation between various services, policies, and infrastructure (Bichir, 2011), in addition to local inequalities and distinct bureaucratic disabilities of the levels of government (Oliveira et al., 2019).

The Program grants R\$ 300.00 (every three months) to families living in extreme poverty and carry out productive activities for sustainable use in the Brazilian agrarian. However, the amount transferred incited increases in the deforestation rate (Carvalho et al., 2020) and failure occurred because the state did not fulfill many commitments (Barros et al., 2020). 
At present, rural social security is generally combined with food, medical consultations, and medicines for residents aged 60 years or older in the RESEX. The financial resources obtained through rural social security, in addition to ensuring basic needs, are shared with the sons living in the same household (Alcântara, 2016; Cazella et al., 2020).

Even with income transfers and retirement, was there deforestation of $42 \%$ (cattle ranching) to ensure the subsistence of the inhabitants of the RESEX of the Pan-Amazon (Maciel et al., 2018; Lavoie \& Brannstrom, 2019; Beresford et al., 2013). Deforestation in RESEX is identified through temporal distribution and deforested hectares at six-year intervals, except the first interval established by the National Institute of Space Research (INPE) (Table 1). For this analysis, data from the INPE were used with the support of the Prodes Project and Monitoring of Changes in Forest Cover, Terra Amazon.

Table 1 - Deforestation in Amazonian RESEX.

\begin{tabular}{|c|c|c|c|c|}
\hline RESEX & $\begin{array}{l}\text { Total area } \\
\text { (hectares) }\end{array}$ & Periods & $\begin{array}{c}\begin{array}{c}\text { Deforestation } \\
\text { (hectares) }\end{array} \\
\end{array}$ & $\%$ \\
\hline \multirow{5}{*}{$\begin{array}{c}\text { Alto } \\
\text { Juruá (Acre) }\end{array}$} & \multirow{5}{*}{537.946} & Before 1999 & 6.540 & 1.21 \\
\hline & & $2000-2005$ & 4.969 & 0.92 \\
\hline & & $2006-2012$ & 4.204 & 0.78 \\
\hline & & 2013-2019 & 2.312 & 0.43 \\
\hline & & & 18.025 & 3.34 \\
\hline \multirow{5}{*}{$\begin{array}{l}\text { Rio Ouro Preto } \\
\text { (Rondônia) }\end{array}$} & \multirow{5}{*}{204.631} & Before 1999 & 7.730 & 3.78 \\
\hline & & $2000-2005$ & 8.966 & 4.39 \\
\hline & & $2006-2012$ & 1.957 & 0.95 \\
\hline & & 2013-2019 & 1.800 & 0.88 \\
\hline & & & 20.453 & 10.00 \\
\hline \multirow{5}{*}{$\begin{array}{l}\text { Rio Cajari } \\
\text { (Amapá) }\end{array}$} & \multirow{5}{*}{532.397} & Before 1999 & 7.720 & 1.45 \\
\hline & & $2000-2005$ & 1.454 & 0.27 \\
\hline & & $2006-2012$ & 2.215 & 0.41 \\
\hline & & 2013-2019 & 1.272 & 0.24 \\
\hline & & & 12.661 & 2.37 \\
\hline
\end{tabular}

Source: Adapted from Inpe/Prodes (2021).

Among the RESEX studied, RESEX Rio Ouro Preto has approximately half the territorial space compared to the others; however, in the second period (6 years), deforestation was more than the first (10 years), both in comparison to its area and the surfaces of the RESEX Alto Juruá and Rio Cajari, in the same period.

In the third interval (2006-2012), Alto Juruá considerably surpassed Rio Ouro Preto and Rio Cajari in terms of deforested area due to the expansion of the cattle herd. Rio Cajari suffered the least environmental impact, because the policy of chestnut extractivism has superior supply and investments compared to Alto Juruá and Rio Ouro Preto.

Continuous deforestation in RESEX is the effect of the growth of agriculture and livestock, especially cattle farming, which requires large areas. The expansion of deforestation is associated with a strong livestock chain and devaluation of the extractive chain (Mascarenhas et al., 2018). The creation of RESEX has not been sufficient to contain deforestation (Santana \& Pedroso, 2019), mainly due to the effects of negative externalities that affect the maintenance of carbon stocks and climate benefits (Fearnside et al., 2018). Thus, it is necessary to carry out empirical research into ecosystem damage (Kröger, 2019).

All the problems identified suggest that the investments prioritized environmental resources. The Pilot Program for the Protection of Tropical Forests of Brazil (PP-G7) was implemented in an international conjuncture in response to the following points: environmental emergency; Brazil's entry into the globalization process; rescue of market confidence (Antoni, 2010); and realization of financial, technical, and technological benefits (Abdala, 2007) among the government, civil society, and the private sector (Kohlhepp, 2018). 
PP-G7 was important because it cooperated with the first four RESEX created in the Amazon (Alto Juruá, ChicoMendes, Rio Ouro Preto, and Rio Cajari) in 1990. The first phase of PP-G7 took place from 1995 to 1999 to carry out social (education and health), environmental (reduction of deforestation and burning), and economic (strengthening of agricultural, extractive, and animal husbandry productive activities) projects. The second phase (2000-2009) was only in the field of negotiations, due to the ineffectiveness observed in the first phase (Mma, 2020) (Table 2).

Table 2 - Investments and priorities in the first phase of PP-G7.

\begin{tabular}{|c|c|c|}
\hline \multicolumn{3}{|c|}{ PP-G7 (1995-1999) } \\
\hline Participating Institutions & Investment & Environmental Priority \\
\hline Brazil & US\$ 0.86 million & Alto Juruá = 537.946 há \\
\hline European Union & US\$ 6.12 million & Chico Mendes $=970.570$ ha \\
\hline Trust Fund for Tropical Forests (RFT) & US\$ 3 million & $\begin{array}{l}\text { Rio Cajari }=532.397 \text { ha } \\
\text { Rio Ouro Preto }=204.631 \text { ha }\end{array}$ \\
\hline Total & US\$ 9.98 million & 2.245.544 hectares \\
\hline
\end{tabular}

Source: Adapted from Mma (2021).

These investments were released to meet the environmental, social, and economic needs of the RESEX but were unsuccessful because of the inefficiency of human and financial capital in the implementation of projects and programs. The PPG7, even with all investments in the first phase (1995-1999), did not guarantee socio-environmental efficacy (Mma, 2020). The confirmation of investments refers to the second phase (2003-2009) of the PP-G7, which was negotiated with a planned investment of US\$10.37 million, but financial resources were suspended due to the ineffectiveness of the first phase (Mma, 2020).

The Protected Areas of the Amazon Program (ARPA) replaced PP-G7 with the objective of ensuring the creation, preservation, and conservation of UCs for full and sustainable use, without any mention of social policies or improvement of life of the inhabitants of these areas. The main funders were the National Bank for Economic and Social Development (BNDES), Kreditanstalt für Wiederaufbau (KFW), and the World Bank Group (WBG).

The ARPA was implemented in 2003 through decree 4.326 in the Amazon RESEX. The ARPA is essential for the conservation of environmental resources (Castro \& Silva, 2017), because it intends to achieve 15\% protection of the Amazon biome by the end of Phase III (in 2039), which is 60 million hectares (Oliveira, 2016) (Table 3).

Table 3 - Investments and priorities in the three phases of ARPA.

\begin{tabular}{l|l|c}
\hline \multicolumn{1}{c|}{ ARPA (2003-2010) } & ARPA (2011-2017) & ARPA (2018-2039) \\
\hline 63 UCs supported & 97 UCs supported & 25 UCs supported \\
\hline 32.5 million of hectares & 17.7 .2 million of hectares & 19.9 million of hectares \\
\hline US \$ $\pm \mathbf{2 4 . 8}$ million & US \$ $\pm \mathbf{1 5 1}$ million & US \$ $\pm \mathbf{1 3 3}$ million \\
\hline
\end{tabular}

Source: Adapted from Mma (2021).

In the second phase (2011-2017), both the number of supported UCs and the areas doubled compared to the first phase (2003-2010), but investments to ensure the conservation and preservation objective decreased. In proportional terms, the same event occurs in the third period (2018-2039) because the forecast time is three times longer than that of the previous stages (21 years) and the resources invested did not double (Mma, 2020).

Strictly speaking, at the time of the PP-G7, despite all the flaws identified, there were policies with environmental, economic, and social purposes, such as education, health, transportation, credit and productive assistance, and extractive, 
agricultural, and animal husbandry programs. In turn, the ARPA specifically makes investments to protect the fauna and flora in UCs.

Extensive environmental conservation of public and environmental institutions has led RESEX to become unsustainable. In this sense, institutional investments prioritize the environment, destructuring the social and economic aspects and consequently impact the environment. The main effects of this are social decline due to increased demands and impacts on environmental resources in an attempt to obtain income.

In general, the state faces difficulties in promoting the conservation of natural resources, the quality of life of the inhabitants, the resolution of illegal actions (deforestation, burning), and conflicts in territory due to lack of socio-environmental integration projects (Goeschl \& Igliori, 2004; Brito \& Treccani, 2019; Paiva et al., 2020). The main causes of these problems are associated with low investments in human and financial capital, devaluation of local participation (Haddad et al., 2019; Costa, 2015; Vivacqua \& Vieira, 2005; Prost, 2018), subsistence difficulties (Maciel et al., 2010), economic crisis of extractive products (Silva \& Paraense, 2019), and livestock growth (Loyola, 2014).

\section{Conclusion}

The poor rural populations of the Amazon region depend on receiving direct government transfers from various programs, such as retirements, Bolsa Família, Seguro Defeso, Bolsa Verde, and recently, the Emergency Assistance for COVID19. Retirements represent the largest sum, equivalent to the monthly minimum wage, highlighting the role of the elderly in the sustainability of inland families. Indirect benefits are access to schools, school lunch programs, school transportation, access to public health, and subsidies for electricity, as this survey demonstrated. It is optimistic to assume that the government will support all UCs in the Amazon, due to the simple unavailability of resources. Unlike developed countries which have a middle class with a high income that allows the maintenance of several parks for access, Brazil has only Tijuca National Park and Iguaçu National Park, which are financially sustainable.

On February nine of two thousand and twenty-one, the federal government created Program Adopt a Park (Decree 10.623), in which 132 UCs in the Legal Amazon were promoted to national and international donors, individuals, or legal entities who want to help aid research for Amazon sustainability. The contribution would be $R$ \$ 10.00/ha/year for nationals and $€ 10$ for foreigners, for a period of five years.

The three RESEX in this study are included in the program and will depend on interested donors. The volume of resources would be quite high compared to the tiny allocations by the Ministry of the Environment: 5.4 million reals for RESEX Alto Juruá, 2 million reais for RESEX Rio Ouro Preto, and 4.8 million reais for RESEX Rio Cajari. With the exception of some "efficiency islands," the passive behavior of residents of many UCs only in view of these benefits has discouraged much support, because those who help end up performing the activities of the beneficiaries. Residents need to be aware that only they will be able to find the means for self-reliance.

During this proposal, the federal government enacted Law 14.119 (13/01/2021), establishing the National Policy for Payment of Environmental Services. There is a danger that "environmental assistance" for a dubious future is being created. To disregard existing intact forest areas which are susceptible to damage, under threat of possible deforestation, or in recovery from degradation, with many unknowns in the medium and long term, is to induce complacency. Therefore, a continued search for productive sustainability is recommended.

This study proves that the Extractive Reserves (RESEX) crisis has occurred because of the relationship of dependence that the environmental, economic, and social groups present with the institution (state). The absence, limitation, and lack of pragmatism in institutional actions provoke negative responses in RESEX. Therefore, we conclude that the implementation of public policies on health, education, transportation, communication, technical assistance, and energy as well as current revenues 
from the productive activities of extractivism, agriculture, and cattle ranching were ineffective, because the state did not cooperate to alleviate the tension between conservation and development. Income from the productive activities of extractivism, agriculture, and cattle raising were low because of low prices and distance from the markets. In addition, even with the investments of PP-G7 and ARPA, there was no balance between conservation and development, because deforestation continued and the living conditions of the residents did not improve. For this reason, it is necessary to reformulate public policies so that there is a balance between conservation and development.

A suggestion for reducing the strain between conservation and development is to improve public health and education policies; organize associations; create cooperatives; effect rural credits; implement technologies to strengthen productive activities of extractivism, agriculture, and cattle ranching; articulate markets for product commercialization; and implement mini brown sugar production factories, mini tobacco processing plants, mini processing plants, and cassava flour packaging and production flow. While these are the main priorities for the RESEX Alto Juruá, Rio Ouro Preto, and Rio Cajari, we emphasize that these suggestions serve all small producers located in any area of the Amazon region.

\section{Acknowledgments}

To the Chico Mendes Institute for Biodiversity Conservation (ICMBio) for providing information and logistical support, especially to managers Albino Batista, Antônio Nonato, Antônio Domingos, Francisco Edenburg, and Simone Santos.

\section{References}

Abdala, F. A. (2007). Governança Global sobre Florestas: o caso do Programa Piloto para Proteção das Florestas Tropicais do Brasil - PP-G7 (1992-2006). Tese (Doutorado em Política Internacional e Comparada) - Instituto de Relações Internacionais, Universidade de Brasília, Brasília. 250.

Alcântara, A. (2016). Envelhecer no contexto rural: a vida depois do aposento. In: Alcântara, A., Camargo, A., \& Giacomin, K. C. Política nacional do idoso: velhas e novas questões. Rio de Janeiro: IPEA. 615.

Allaire, G. (2010). Applying economic sociology to understand the meaning of quality in food Markets. International Association of Agricultural Economists, 41, $167-180$.

Allegretti, M. (1990). Alternatives do Deforestation: steps towards sustainable use of the Amazon rain forest. In: Anderson, A. B. (Org.). Alternatives to deforestation: steps towards sustainable use of the Amazon rain forest. New York: Columbia University Press, 252-264.

Allegretti, M. H. (2008). A construção social de políticas públicas. Chico Mendes e o movimento dos seringueiros. Desenvolvimento e Meio Ambiente, 18, 39-59.

Allegretti, M. H. (2002). A Construção social de políticas públicas. Chico Mendes e o movimento dos seringueiros. (Programa de Pós-Graduação em Desenvolvimento Sustentável - CDS/UNB. 827.

Allegretti, M. H., \& Schwartzman, S. (1987). Extractive Reserves: a sustainable development alternative for Amazonia. Project US-478. WWF (US), Whashington, $D C$.

Almeida, A. W. B. (2004). Terras Tradicionalmente Ocupadas: processos de territorialização e movimentos sociais. Revista Brasileira de Estudos Urbanos e Regionais, 6(1), 9-32.

Almeida, M. W. B., Allegretti, M. H., \& Postigo, A. (2018). O legado de Chico Mendes: êxitos e entraves das Reservas Extrativistas. Desenvolvimento e Meio Ambiente, v. 48, p. 25-31. https://doi.org/10.5380/dma.v48i0.60499. e-ISSN 2176-9109

Anderson, A. A. (1990). Alternatives to Deforestation: Steps Toward Sustainable Use of the Amazon Rain Forest, New York: Columbia University Press.

Antoni, G. (2010). O Programa Piloto para Proteção das Florestas Tropicais do Brasil (PP-G7) e a globalização da Amazônia. Ambiente \& Sociedade, 13(2), 299313.

Barros, V. C. C., Souza, R. H. P., Marques, R. T., \& Borges, L. A. C. (2020). Pagamento por serviço ambiental: panorama do programa bolsa verde do estado de minas gerais. Revista em Agronegócio e Meio Ambiente, 13(4), 1347-1363.

Beresford, A. E., Eshiamwata, G. W., Donald, P. F., Balmford, A., Bertzky, B., Brink, A. B., Fishpool, L. D. D., Mayaux, P., Phalan, B., Simonetti, D., \& Buchanan, G. M. (2013). Protection Reduces Loss of Natural Land-Cover at Sites of Conservation Importance across Africa. PloS ONE, 8(5), 65370. https://doi.org/10.1371/journal.pone.0065370

Bezerra, J. (2012). A Amazônia na Rio + 20: as discussões sobre florestas na esfera internacional e seu papel na Rio + 20. Cadernos EBAPE, 10, 533-544.

Bichir, R. M. (2011). Mecanismos federais de coordenação de políticas sociais e capacidades institucionais locais. 2011. Tese de Doutorado, Universidade Federal do Rio de Janeiro, Rio de Janeiro. 
Bockstael, E., Bahia, N., Seixas, C., \& Berkes, F. (2016). Participation in Protected Area management planning in coastal Brazil. Environmental Science \& Policy, $60,1-10$.

Bolčić, S. (2014). New trends in the economic sociology in the USA. Sociologia. 46(2), 125-142.

Boltanski, L., \& Chiapello, E. (1999). Le nouvel esprit du capitalisme. Paris, Gallimard.

Brasil. (2010). Instituto Brasileiro de Geografia e Estatística $\quad$ (IBGE). Censo demográfico. http://ww2.ibge.gov.br/home/estatistica/populacao/censo2010/default.shtm. Access in: 8 set. 2020.

Brasil. (2021). Instituto Chico Mendes de Conservação da Biodiversidade (ICMBio). Unidades de Conservação. https://www.icmbio.gov.br/portal/unidadesdeconservacao/biomas-brasileiros. Access in: 12 apr. 2021

Brasil. (2020). Instituto Nacional de Pesquisas Espaciais - INPE. Quanto já foi desmatado na Amazônia? Disponível em: http://www.inpe.br/faq/index.php?pai=6. Access in: 15 dez. 2020.

Brasil. (2018). Ministério do Meio Ambiente. Subsídios ao Planejamento da Gestão Ambiental. Brasília: Distrito Federal. http://www.mma.gov.br/areas-protegidas. Access in: 7 out. 2020.

Brito, S. V., \& Treccani, G. D. (2019). Unidades de conservação na Amazônia e territorialidades específicas: o caso da Reserva Extrativista de Ipaú-Anilzinho. Revista de Direito e Sustentabilidade, 5(2), 95-113.

Browder, J. O. (1992). The limits of extractivism: tropical forest strategies beyond extractive reserves. BioScience, 42, 174-182.

Brown, K., \& Rosendo, S. (2000). Environmentalists, rubber tappers and empowerment: the politics and economics of Extractive Reserves. Development and Change, $31,201-227$.

Calegare, M. G. A., \& Higuchi, M. I. G. Participatory action research in an Amazon protected area: Lessons for community psychology in Northern Brazil. Journal of Community \& Applied Social Psychology, 28(6), 1-11, 2018. https://doi.org/10.1002/casp.2379

Capelari, M. G. M., Gomes, R. C., Araújo, S. M. V. G.; \& Newton, P. (2020). Governance and deforestation: understanding the role of formal rule-acknowledgement by residents in brazilian extractive reserves. International Journal of the Commons, 14(1), 245-261. https://doi.org/10.5334/ijc.966

Carvalho Ribeiro, S. M., Soares-Filho, B., Leles Costa, W., Bachi, L., Ribeiro, O. A., Bilotta, P., \& Cioce Sampaio, C. (2018). Can multifunctional livelihoods including recreational ecosystem services (RES) and non timber forest products (NTFP) maintain biodiverse forests in the Brazilian Amazon? Ecosystem Services, $31,517-526$.

Carvalho, A. V., Carvalho, R. A. F., Carvalho, D. G., \& Guimarães, J. L. C. (2020). Análise do Programa Bolsa Verde na Amazônia Legal sob a hipótese da Curva de Kuznets Ambiental. Revista Ciências da Sociedade, 4(7), 69-89.

Castro, B. T. C., \& Silva, A. T. A. (2017). Cooperação Internacional para o Desenvolvimento da Amazônia: a experiência do Programa ARPA. Novos Cadernos NAEA, 20(2), 149-164.

Cavalcante, F. R. C., \& Góes, S. B. (2011). O Desafio da Gestão Ambiental em Rondônia: um estudo sobre a pressão agropecuária nos municípios com e sem Unidades de Conservação da Natureza. In: Congresso Brasileiro de Gestão Ambiental. Londrina: IBEAS. 1-14.

Cazella, A., Capellesso, A. J., \& Schneider, S. (2020). A abordagem do Não-Recurso a políticas públicas: o caso do crédito rural para a agricultura familiar. Revista Política e Planejamento Regional, 7(1), 48-67.

Choksi, P. (2020). Examining patterns and impacts of forest resource extraction and forest degradation in tropical dry forests. In: Bhadouria, R., Tripathi, S., Srivastava, P., Sngh, P. (2020). Handbook of Research on the Conservation and Restoration of Tropical Dry Forests. IGI Global Core Reference Title, 171-192. https:/doi.org/10.4018/978-1-7998-0014-9.ch009

Clement, C. (2006). A lógica do mercado e o futuro da produção extrativista. In: Kubo. R., Bassi J. B.., Souza, C., Alencar, N. L., Medeiros, P., \& Albuquerque, U. (Org.). Atualidades em etnobiologia e etnoecologia. Recife: Nupeea/SBEE.

Cochet, H. (2008). Vers une nouvelle relation entre la terre, le capital et le travail. Etudes foncières, 134, 24-29.

Collins, B. M., \& Mitchard, A. T. E. (2017). A small subset of Protected Areas are a highly significant source of carbon emissions. Scientific Reports, 7(41902), $1-11$.

Corrigan, C., Bingham, H., Shi, Y., Lewis, E., Chauvenet, A., \& Kingston, N. (2018). Quantifying the contribution to biodiversity conservation of protected areas governed by indigenous peoples and local communities. Biological Conservation, 227, 403-412. https://doi.org/10.1016/j.biocon.2018.09.007

Costa, F. A. (2012). Formação rural extrativista na Amazônia: os desafios do desenvolvimento capitalista (1720-1970). Belém: NAEA. 154.

Costa, M., Fraxe, T., Santiago, J., \& Vasques, M. (2015). A Educação Escolar nas Unidades de Conservação: entre os desafios e possibilidades de processos educativos diferenciados. In: Pereira, H., Fraxe, T., Costa, F., \& Witkoski, A. (Org.). Unidades de Conservação do Amazonas no Interflúvio Purus-Madeira: diversidade cultural e gestão social dos bens comuns. Manaus: EDUA.

Costa, P. C. P. (2018). Reservas Extrativistas Marinhas: reflexões sobre desafios e oportunidades para a cogestão em áreas marinhas protegidas. Desenvolvimento e Meio Ambiente, 48, 417-431. https://doi: 10.5380/dma.v48i0.58793

Cunha, M. C., \& Almeida, M. W. B. (2004). Traditional populations and environmental conservation. In: Veríssimo, A., Moreira, A., Sawyer, D., Santos, I., Pinto, L. P. (Eds.). Biodiversity in the Brazilian Amazon. São Paulo: Editora Estação Liberdade, 182-191. 
Dantas, C. M. B., Dimesntein, M., Leite, J. F., Macedo, J. P., \& Belarmino, V. H. (2020). Território e determinação social da saúde mental em contextos rurais: cuidado integral às populações do campo. Athenea Digital, 2(1), 1-21. https://doi.org/10.5565/rev/athenea.2169

Drummond, A. J., \& Franco, A. L. J., Oliveira, D. (2012). An assessment of Brazilian Conservation Units - a second look. Novos Cadernos NAEA, 15(1), 53-83.

Drummond, J. A. (1996). A extração sustentável de produtos florestais na Amazônia brasileira: vantagens, obstáculos e perspectivas. Estudos Sociedade e Agricultura, $6,115-137$.

Elster, J. (1994). Peças e Engrenagens das Ciências Sociais. Rio de Janeiro: Relume Dumara. 106.

Fearnside, P. (1996). Extractivism in the Brazilian Amazon: perspectives on regional development Ed. Miguel Clüsener-Godt and Ignacy Sachs 88 pp., $24 \times 16 \times 0.7$ cm, MAB Digest 18, Paris, France: UNESCO, 1994. Environmental Conservation, 23(4), 1-5.

Fearnside, P. M., Nogueira, E. U., \& Yanai, A. M. (2018). Maintaining carbon stocks in Extractive Reserves in Brazilian Amazonia. Desenvolvimento e Meio Ambiente, 48, 446-476. https://doi: 10.5380/dma.v48i0.58780

Françoso, R., Brandão, R., Nogueira, C., Salmona, Y., Machado, R., \& Colli, G. (2015). Habitat loss and the effectiveness of Protected Areas in the Cerrado Biodiversity Hotspot. Natureza \& Conservação, 13, 35-40.

Freitas, J. S. (2018). Conflitos entre Sobrevivência Familiar e Conservação Ambiental em Reservas Extrativistas da Amazônia. Tese (Doutorado em Desenvolvimento Sustentável do Trópico Úmido) - Núcleo de Altos Estudos Amazônicos, Universidade Federal do Pará, Belém. 166.

Freitas, J. S., \& Rivas, A. F. (2014). Unidades de Conservação promovem pobreza e estimulam agressão à natureza na Amazônia. Revista de Gestão Social e Ambiental, 8(3), 18-34. https://doi.org/10.24857/rgsa.v8i3.969

Freitas, J. S., Silva, D., \& Rodrigues, M. (2016). Areas Protegidas en el Amazon: un análisis institucional Extractiva Reserva el Alto Jurua. Contribuciones a Las Ciencias Sociales, 6, 1-13.

Geisler, C., \& Silberling, L. (1992). Extractive reserves as alternative land reform: Amazonia and appalachia compared. Agriculture and Human Values, 9, 58-70.

Goeschl, T., \& Igliori, D. (2004). Reconciling conservation and development: a dynamic hotelling model of extractive reserves. Land Economics, 80(3), 340-354.

Gomes, C., Vadjunec, J., \& Perz, S. (2012). Rubber tapper identities: political-economic dynamics, livelihood shifts, and environmental implications in a changing Amazon. Geoforum, 43, 260-271.

Granovetter, M. (2000). Le marché autrement. Paris: Desclée de Brouwer. Coletânea de cinco artigos traduzidos para o francês.

Greissing, A. (2010). A região do Jari, do extrativismo ao agronegócio: as contradições do desenvolvimento econômico na Amazônia florestal no exemplo do projeto Jarí. $R E U, 36(3), 43-75$.

Haddad, R. D., Haddad, M. D., Melo, C. M., Madi, R., \& Coelho, A. S. (2019). Análise social, econômica e histórica das Reservas Extrativistas da Amazônia: lutas e trajetórias. Espacio Abierto, 28(2), 85-102.

Hall, A. (2004). Political economy extractive reserves: Building natural assets in the Brazilian Amazon. Political Economy Research Institute, 74, 1-17.

Hall, A. (1997). Sustaining Amazonia: Grassroots Action for Productive Conservation, Manchester: Manchester University Press.

Harff, Y., \& Lamarche, H. (1988). Le travail en agriculture: Nouvelles demandes, nouveaux enjeux. Economie rurale, $244,3-11$.

Hecht, S. (2013). In the realm of rubber, the scrumble for the Amazon and the lost paradise of Euclides da Cunha. Chicago: The University of Chicago Press.

Homer-Dixon, T. (2006). The upside of down. Catastrophe, creativity, and the renewal of civilization. In: ALfred A. K. Random House, Canada.

Homma, A. K. O. (2012). Extrativismo vegetal ou plantio: Qual a opção para a Amazônia? Estudos Avançados, 26(74), 167-186. https://doi.org/10.1590/S010340142012000100012

Homma, A. K. O. (2020). Amazônia: a civilização do fogo. In: Alves, R. N. B., \& Modesto Júnior, M. S. Roça sem Fogo: da tradição das queimadas à agricultura sustentável na Amazônia. Brasília: Embrapa, 11-33.

Homma, A. K. O. (2018). Colhendo da natureza: o extrativismo vegetal na Amazônia. $1^{\text {a }}$ ed. Brasília: Embrapa.

Homma, A. K. O. (2015). Em favor de uma nova agricultura na Amazônia. In: Lindomar, S., Adriano, P., Ariane, M.; Tassiana, S., Albejamere, C., Costa, E. A., Gutemberg, G., Ferreira, M., \& Vidal, J. Terceira Margem Amazônia. São Paulo: Outras Expressões.

Homma, A. K. O. (2013). História da agricultura na Amazônia: da era pré-colombiana ao terceiro milênio. 2. ed. Brasília: Embrapa. 274.

Humphries, S., Holmes, T. P., Kainer, K., Gabriel, C., Koury, G., Cruz, E., \& Miranda, R. (2012). Are community-based forest enterprises in the tropics financially viable? Case studies from the Brazilian Amazon. Ecological Economics, 77, 62-73. https://doi. org/10.1016/j.ecolecon.2011.10.018.

Jaramillo-Giraldo, C., Soares-Filho, B., Ribeiro, S. M., \& Gonçalves, R. C. (2017). Is it possible to make rubber extraction ecologically and economically viable in the Amazon? The Southern Acre and Chico Mendes reserve case study. Ecological Economics, 134, 186-197. https://doi.org/10.1016/j.ecolecon.2016.12.035

Kainer, K. A., Wadt, L. H. O., \& Staudhammer, C. L. (2018). The evolving role of Bertholletia excelsa in Amazonia: contributing to local livelihoods and forest conservation. Desenvolvimento e Meio Ambiente, 48, 477-497. https://doi.org/10.5380/dma.v48i0.58972. e-ISSN 2176-9109 
Kohlhepp, G. (2018). O Programa Piloto Internacional de Proteção das Florestas Tropicais no Brasil (1993-2008): as primeiras estratégias da política ambiental e de desenvolvimento regional para a Amazônia Brasileira. Revista NERA, 21(42), 309-331.

Krasnov, E. V. (2020). From nature conservation to sustainable development. In: Fedorov, G., Druzhinin, A., Golubeva, E., Subetto, D., \& Palmowski, T. (Orgs.). Baltic Region - The Region of Cooperation. Springer Proceedings in Earth and Environmental Sciences, 111-120. https://doi.org/10.1007/978-3-030-14519-4

Kröger, M. (2019). Deforestation, cattle capitalism and neodevelopmentalism in the Chico Mendes Extractive Reserve, Brazil. The Journal of Peasant Studies, 1-19. https://doi.org/10.1080/03066150.2019.1604510

Lavoie, A., \& Brannstrom, C. (2019). Assembling a Marine Extractive Reserve: the case of the Cassurubá RESEX in Brazil. Journal of Latin American Geography, 18(2), 120-151. https://doi.org/10.1353/lag.2019.0036

Liljenberg, A. (2005). A socio-dynamic understanding of markets: the progressive joining forces of economic sociology and Austrian. The American Journal of Economics and Sociology, 64(4), 999-1023.

Lopes, E., Soares-Filho, B., Souza, F., Rajão, R., Merry, F., \& Carvalho Ribeiro, S. (2018). Mapping the socio-ecology of Non Timber Forest Products (NTFP) extraction in the Brazilian Amazon: the case of açaí (Euterpe precatoria Mart) in Acre. Landscape and Urban Planning, 30(40), 1-8. https://doi.org/10.1016/j.landurbplan.2018.08.025

Loyola, R. (2014). Brazil cannot risk its environmental leadership. Divers. Distrib. 20, 1365-1367. https://doi.org/10.1111/ddi.12252

Maciel, R. C. G., Almeida, A. M., \& Menezes, H. C. S. (2018). Avaliação econômica da pecuária de gado na Reserva Extrativista Chico Mendes. In: $56^{a}$ Congresso Brasileiro de Administração, Economia e Sociologia Rural (SOBER); 2001, 29 jul a $1^{\circ}$ de ago; Campinas: Unicamp.

Maciel, R. C. M., Cavalcante, F. C. S., Souza, E. F., Oliveira, O. F., \& Cavalcante Filho, P. G. (2018). The Chico Mendes Extractive Reserve and land governance in the Amazon: some lessons from the two last decades. Journal of Environmental Management, 223, 403-408.

Maciel, R., Reydon, B., Costa, J., \& Sales, G. (2010). Pagando pelos serviços ambientais: uma proposta para a Reserva Extrativista Chico Mendes. Acta Amazônia, 40(3), 489-498.

Mascarenhas, F. S., Brown, I. F., \& Silva, S. (2018). Desmatamento e incêndios florestais transformando a realidade da Reserva Extrativista Chico Mendes. Desenvolvimento e Meio Ambiente, 48, 236-262. https://doi: 10.5380/dma.v48i0.58826

Mcadam, D., Mccarthy, J. D., \& Zald, M. N. (1996). Conceptual origins, current problems, future directions, Comparative Perspectives on Social Movements. Cambridge: Cambridge Univ. Press.

Merry, F., \& Soares-Filho, B. (2017). “Will Intensification of Beef Production Deliver Conservation Outcomes in the Brazilian Amazon?” Elem Sci Anth, 5(24), 112. https://doi.org/10.1525/elementa.224

Mooij, M. L. J., Mendonça, S. D., \& Arts, K. (2019). Conserving biocultural diversity through community-government interaction: a practice-based approach in a Brazilian Extractive Reserve. Sustainability, 11(32), 2-18. htpps://doi.org/10.3390/su11010032

Nepstad, D., Schwartzman, S., Bamberger, B., Santilli, M., Schlesinger, P., Lefebvre, P., Alencar, A., Ray, D., Prinz, E., \& Rolla, A. (2006). Inhibition of Amazon deforestation and fire by parks and indigenous reserves. Conservation Biology, 20(1), 65-73.

Oliveira, D. (2012). A estratégia do Programa Áreas Protegidas da Amazônia para avaliar a efetividade das Unidades de Conservação. Tese (Doutorado em Desenvolvimento Sustentável) - Centro de Desenvolvimento Sustentável, Universidade de Brasília, Brasília. 212.

Oliveira, V. E., Lotta, G. S., \& Nunes, M. (2019). Desafios de implementação de uma política intersetorial e federativa: as burocracias de médio escalão do Programa Bolsa Família. Revista de Serviço Público, 70(3), 458-485.

Paiva, P. F. P. R., Ruivo, M. P., Silva J., O. M., Maciel, M. N. M., Braga, T. G. M., Andrade, M. N., Santos, J. P. C., Rocha, E. S., Freitas, T. M., Silva L. T. V., Oliveira, O. H., Gama, M., Sousa S. L., Silva, M. G., Silva, E. R., \& Ferreira, B. M. (2020). Deforestation in protect areas in the Amazon: a threat to biodiversity. Biodiversity and Conservation, 29, 19-38. https://doi.org/10.1007/s10531-019-01867-9

Pantoja, M., Costa, E., \& Postigo, A. (2009). A presença do gado em Reservas Extrativistas: algumas reflexões. Revista Pós Ciências Sociais, 6(12), 115-130.

Pédelahore, P., Uwizeyimana, L., Wainaina, C. T. C., \& Vaast, P. (2020). Contribution to a renewed framework to analyse the interactions between family and capitalist agriculture. Journal of Agrarian Change, 20(2), 1-90. https://doi.org/10.1111/joac.12358

Peres, C. A. (2000). Effects of subsistence hunting on vertebrate community structure in Amazonian forests. Conservation Biology, 14(1), 240-253.

Prost, C. (2018). Reservas extrativistas marinhas: avanço ou retrocesso? Desenvolvimento e Meio Ambiente, 48, 321-342. https://doi.org/10.5380/dma.v48i0.58351

Quaresma, B. D. H. (1998). Unidades de Conservação da Natureza como instrumento de políticas públicas. Paper do NAEA, 114, 1-25.

Redford, K. H. (1992). The Empty Forest. BioScience, 42(6), 412-422.

Rohde, M. M., Reynolds, M., \& Howard, J. (2020). Dynamic multibenefit solutions for global water challenges. Conservation Science and Practice, 2(144), 1-8. https://doi.org/10.1111/csp2.144

Rylands, A. B., \& Brandon, K. (2005). Brazilian Protected Areas. Conservation Biology, Washington, 19(3), 612-618. https://doi.org/10.1111/j.15231739.2005.00711.x

Salisbury, D., \& Schmink, M. (2007). Cows versus rubber: changing livelihoods among Amazonian extractivists. Geoforum, 38, $1233-1249$. 
Research, Society and Development, v. 10, n. 5, e11610514631, 2021

(CC BY 4.0) | ISSN 2525-3409 | DOI: http://dx.doi.org/10.33448/rsd-v10i5.14631

Santana, R. S., \& Pedroso, S. C. (2019). Evaluation of the advancing deforestation in the state Extractive Reserve of Jaci-Paraná - RO, between 1996 and 2016. Terra@Plural, 13(1), 93-105. https://doi:10.5212/TerraPlural.v.13i1.0006

Sawyer, D. (2013). Chico Mendes e o Mundo. Textos eco-sociais 14-03. Brasília: Instituto Sociedade, População e Natureza - ISPN.

Schwartzman, S. (2018). Chico Mendes, the rubber tappers and the indians: reimagining conservation and development in the Amazon. Desenvolvimento $e$ Meio Ambiente, 48, 56-73. https://doi.org/10.5380/dma.v48i0.58829. e-ISSN 2176-9109

Schwartzman, S. (1986). World Bank holds funds for development project in Brazil. Cultural Survival Quarterly Magazine. Cambridge MA: Cultural Survival.

Shanley, P., Silva, F. C., Mcdonald, T., \& Silva, M. S. (2018). Women in the wake: expanding the legacy of Chico Mendes in Brazil's environmental movement. Desenvolvimento e Meio Ambiente, 48, 140-166. https://doi.org/10.5380/ dma.v48i0.58834. e-ISSN 2176-9109

Silva, A. S. O., \& Paraense, V. C. (2019). Production chain for brazil-nuts (bertholletia excelsa Bonpl.) at Ipaú-Anilzinho Extractive Reserve, municipality of Baião, Pará, Amazonian Brazil. Revista Agro@mbiente, 13, 68-80. http://doi.10.18227/1982-8470ragro.v13i0.5413

Silva, A., Braga, M. Q., Ferreira, J., Santos, V. J., Alves, S. C., Oliveira, J. C., \& Calijuri, M. L. (2020). Anthropic activities and the legal Amazon: estimative of impacts on forest and regional climate for 2030. Journal Pre-proof, 1-19. https://doi.org/10.1016/j.rsase.2020.100304

Silva, H. R. O., \& Silva, S. C. P. G. (2019). Unidades de Conservação e desmatamento na Amazônia: análise do Parque Estadual de Guajará Mirim em Rondônia/Brasil. Acta Geográfica, 13(32), 156-170.

Silveira, E. M. (2018). Chico Mendes: coragem e ternura na resistência acreana. Desenvolvimento $e$ Meio Ambiente, 48, 7-24. https://doi.org/10.5380/dma.v48i0.58819. e-ISSN 2176-9109

Simioni, G., Marie, M., Davi, H., Paul, N. M., \& Huc, R. (2020). Natural forest dynamics have more influence than climate change on the net ecosystem production of a mixed mediterranean forest. Ecological Modelling, 416(108921), 1-9. https://doi.org/10.1016/j.ecolmodel.2019.108921

Siviero, A., Teixeira, P. E. F., \& Santos, R. C. (2019). A produção agropecuária nas reservas extrativistas do Acre. In: Siviero, A., Santos, R. C., \& Mattar, E. P. L. Conservação e tecnologias para o desenvolvimento agrícola e florestal do Acre. $1^{\mathrm{a}}$. ed. Rio Branco: IFAC, 337-378.

Smeraldi, R., \& May, P. (2008). O Reino do Gado: Uma Nova Fase na Pecuarização da Amazônia Brasileira. São Paulo: Amigos da Terra-Amazônia Brasileira.

Soares-Filho, B., Rodrigues, H., \& Follador, M. (2013). A hybrid analytical-heuristic method for calibrating land-use change models. Environmental Modelling and Software, 43, 80-87. https://doi.org/10.1016/j.envsoft.2013.01.010

Steiner, P. (2007). A sociologia econômica. São Paulo: Atlas.

Steiner, P. (2005). Le Marché selon la sociologie économique. Sociales, 63(132), 31-54.

Stropp, J., Umbelino, B., Correia, R. A., Campos-Silva, J. V., Ladle, R. J., \& Malhado, A. C. M. (2020). The ghosts of forests past and future: deforestation and botanical sampling in the Brazilian Amazon. Nordic Society Oikos, 43, 1-11. https://doi.org/ 10.1111/ecog.05026

Teixeira, T. H., Nottinghan, M. C., Ferreira Neto, J. A., Estrela, M. B., Santos, B. V. S., \& Figueiredo, N. A. (2018). A diversidade produtiva em Reservas Extrativistas na Amazônia: entre a invisibilidade e a multifuncionalidade. Desenvolvimento e Meio Ambiente, 48, 164-183. https://doi.org/10.5380/dma.v48i0.58805. e-ISSN $2176-9109$

Thaler, G. M., Viana, C., \& Toni, F. (2019). From frontier governance to governance frontier: the political geography of Brazil's Amazon transition. World Development, 114, 59-72.

Turini, E. T. (2014). Proposta de preços mínimos safra 2013/2014. Produtos da sociobiodiversidade. In: Proposta de preços mínimos, 3, 5-19.

Vadjunec, J. M., Gomes, C. V. A., \& Ludewigs, T. (2009). Land-use/land-cover change among rubber tappers in the Chico Mendes Extractive Reserve, Acre, Brasil. Journal of Land Use Science, 4(4), 249-274. https://doi.org/10.1080/17474230903222499

Vivacqua, M., \& Vieira, P. (2005). Conflitos Socioambientais em Unidades de Conservação. Revista Política \& Sociedade, 7, $139-162$.

Volpato, G. L. (2016). Estatistica sem dor. 2 ed. Botucatu: Best Writing. 288

Volpato, G. L. (2013). Ciência: da filosofia à publicação. 6 ed. São Paulo: Cultura Acadêmica. 377.

Volpato, G. L. (2015). O método lógico de redação científica. Reciis, 9(1), 1-14.

Walker, W. S., Gorelik, S. R., Baccini, A., Aragon-Osejo, J. L., Josse, C., Meyer, C., Macedo, M. N., Augusto, C., Rios, S., Katan, T., Souza, A., Cuellar, S., Lianos, A., Zager, I., Mirabal, G. D., Solvik, K., Farina, M. K., Moutinho, P., \& Schwartzman, S. (2020). The role of forest conversion, degradation, and disturbance in the carbon dynamics of Amazon Indigenous Territories and Protected Areas. Environmental Sciences, 117(6), 3015-3025. https://doi.org/10.1073/pnas.1913321117

Wallace, R. H., Gomes, C. V. A., \& Cooper, N. A. (2018). The Chico Mendes Extractive Reserve: trajectories of agroextractive development in Amazonia. Desenvolvimento e Meio Ambiente, 48, 184-213. https://doi.org/10.5380/dma.v48i0.58836. e-ISSN 2176-9109

White, H. C. (1981). “Where do markets come from?” American Journal of Sociology, 87(3), 517-547. https://doi.org/10.1086/227495 